\title{
Developing Character Education Grounded on "Abk" (Attitude Before Knowledge) Model for Kindergarten at Raudlatul Athfal State Islamic University 'Sunan Kalijaga' Indonesia
}

\author{
By: Radjasa, Sri Sumarni, Istiningsih \\ Lecturers at Faculty of Tarbiyah\& Teaching, 'Sunan Kalijaga' State Islamic University Indonesia
}

\begin{abstract}
Indonesian formal education's orientation has been focused on the development of science and technology (hard skills), therefore, it is weak in developing moral and spiritual components (soft skills). This, inevitably, is linked with the multi-dimensional crisis that we experience today - widely assumed as the impact of the economic crisis. As an effort to deal with the crisis, education in Indonesia has been focused to develop science and technology, which are considered as capitals for the economic development. Unfortunately, this imbalanced practice in education has created another crisis instead, i.e. the value crisis. To strengthen the education of value or character, innovation is needed in the practice of education, especially in early age education, because education in this age is the foundation for character development in the later ages. Raudhatul Athfal Dharma Wanita Persatuan (RA-DWP) is a pre-school educational institution which is used as one of the educational laboratories for students of Tarbiyah Sciences Faculty and Teacher Training Faculty, 'Sunan Kalijaga' State Islamic University, Indonesia, to conduct their apprenticeship program. The changes that take place in this institution will have a vast impact, as vast as the impact experienced by the faculty students who study here.This research aims to design a model of education at RA-DWP. The research method chosen is Research and Development $(R \& D)$, which involves the following steps: first, conduct a need assessment, after that, dig the 'lesson learned' model from Japan, and then design a model which is appropriate for the needs, the proposed models are validated by experts and practitioners to come up with the most suitable one. Japan is chosen as a reference because it is well known as a country which has successfully developed character education. The model developed includes a philosophical basis, a model concept and an operational model.The 'need assessment' study results show that RA-DWP needs to strengthen the vision of character education, both in concept and implementation. Therefore, the 'lesson learned' from Japan is very relevant to redesign the said educational model. After conducting several research steps and adopting the theory of value education from Lickona, the ABK (Attitude Before Knowledge) model is established. This model demands three important aspects: exemplary conduct by teachers and parents, development of conducive school culture, and close cooperation between the school and all other stakeholders. With this ABK model, students will be able to enter the global world with sufficient knowledge and skills, and will have the characteristics of civilized citizens. Keyword: Character education model, kindergarten.
\end{abstract}

\section{Introduction}

Education in Indonesia is confronted with a very serious problem, i.e. the worsening value system and attitudes of the people. The stigma that Indonesia is an unsafe country, ridden with corruption, plagued with red tape, and burdened by conflicts between groups in the society, hasn't been challenged by all components of the nation. Even the administration of national education is getting farther and farther away from offering solutions to society's problems, therefore, society's behaviors do not represent the identity of educated people, regardless of level of education. Schools no longer serve as as the place where students gain a good education, rather, they solely function as a place where people learn about science and technology. In the concept of year 2013 curriculum, although elements of affection and motoric are given a good portion of attention, the implementation is still far from expectation.

The deficiency of character education has produced irresponsible individuals. The system of democracy applied in the society that lacks responsibility will only create a paradox, that is, the emergence of anti-democratic actions. The positive values contained in the system of democracy such as appreciation of differences, mutual assistance, trust in each other, and putting common interest ahead of personal interest continue to disappear in the society's life. The disappearance of positive values from the society's life has triggered criticisms from scientists and culturalists. Take for example T. Ya'cub (1999), and Nasution (2011), who said that Indonesia is heading towards a kleptocratic country. Muchtar Lubis called Indonesian people as hypocrite and irresponsible (1978). This paradox phenomenon is inseparable from the imbalanced practice in the national education system, the system which emphasizes on results rather than process, in contrast with what Kolb expressed, "learning is a continuous process grounded in experience" (David A. Kolb, 1984, p. 27). 
Consequently, teachers only serve as instructors, not as educators. What the teachers do is simply follow the curriculum, not guide the students along and instill values throughout the teaching-learning process so that the students develop into respectable individuals who are ready to face the challenges of the future. Schools also focus on the development of intellect by teaching science and technology as early as possible, instead of improving students' attitudes and behaviors. In short, character education is hardly touched by teachers at schools, hardly noticed by parents at home, and hardly controlled by the society.

During a conference on national education, held in cooperation with the Department of Education and Culture, BAPPENAS, Asia Development Bank, and World Bank in 1999, when Indonesia was under crisis, it was evident that the substance discussed was how to improve the teaching process at schools to produce 'smart children' who master science and technology. Consequently, students were heavily burdened with a number of subjects which are mostly cognitive in nature. Affective and motoric activities such as arts, sports, skills and scouting are considered unimportant. Truly, the government's policy after the multi-dimensional crisis, which started in 1998, was focused on the development of the economy, because the reality that we faced was the failure of Indonesia' economy. But it would be a fundamental error if we assume that the economic weakness was merely due to the weakness of science and technology. Economic problem is closely related with workculture and religious rationality (Weber, 1967), it is also related with cooperative culture and corporate culture (Phillip Farish, 19820, also with organization culture (Reynold, 1993), and so on, all of which are soft skills and society characters that are beyond science and technology.

The next problem is the fact that this imbalanced educational patterns span further to reach practices in the early age education. Organizers of early age education were forced to practice cognitive-skills-oriented teaching, because even the society demands that their children can learn to read, write and count way before they enter the elementary school. This was worsened by the fact that many elementary schools screened their prospective students on the basis of their ability to read and write. Consequently, almost all early education institutions offer reading, writing and counting lessons despite the fact that such a practice is against the nature of child development, which should contain more chances to engage in game and play, which constitutes children's basic rights.

Early childhood education that is based on Islamic teachings has an even bigger problem, here, religion is given as a separate subject, intensely characterized by knowledge and rote learning contents. The content on religion for these schools, displayed as the Islamic schools' unique identity, is prepared by the Ministry of Religious Affairs; it consists of religious knowledge, reading and writing of the Qur'an, reciting the Qur'an and reciting other prayers. Such contents are roughly the same as those given to students of elementary and secondary schools. The sooner these young children learn about religion and can memorize verses and prayers, the better. But actually, children who are accustomed to think and behave according to the religious teachings will be better than those who learn the religion cognitively and through a lot of memorization.

Children's behavior in countries which give precedence to character education such as New Zealand, Finland, South Korea and Japan, appear more Islamic than the behavior of those from countries that teach religion the way it is like in Indonesia. Countries in which the citizens' social lives are more Islamic are not countries with Islam majority citizens and who formally teach Islam, but those in which Islamic values are practiced through education. This is in line with what Hossein Asykari and S. Rahman (2010) stated in Global Economy Journal volume 10 issue 3 September 2010 on 'Economic Islamicity Index.' Therefore, the learning process which offers religious experience and accustomization is more beneficial for preschoolers than the teaching of religious materials. This matter needs to be wisely responded by stakeholders of Islamic education. Efforts to improve the process of religious education need to be maintained so as not only become knowledge but also manifested as attitude and behavior.

Raudlatul Athfal (RA), administered under the management of Universitas Islam Negeri, is a preschool based on Islamic teaching. RA serves as an education laboratory where prospective teachers perform their practicum teaching. The similar situation is experienced by other RAs, they are burdened by learning materials, including religious teachings, and they lack activities which promote students' affection and motoric development. If the learning process at the RA is not resolved, it will not produce competent teachers. Therefore, we need to reformulate the design of character education at the RAs as a model for prospective teachers and prospective RA operators who are studying at the University.The best way to improve the process of learning is by performing a benchmark against preschool education institution from a country that is considered successful in applying character-building-based education process. The most suitable choice for this is Japan.

\section{Objective}

This research aims to redesign the teaching model at RA UIN Sunan Kalijaga based on character building by taking the lesson and experience from Japan, that is, from 'Takasaka Kindergarten'. In detail, the model includes: 
1. The philosophy of early age education.

2. The concept of character education for early age children.

3. Operationalization of the concept of character education.

To produce such a design, this research uses a research and development (R\&D) approach. The stages include: digging for need assessment, model study from an advanced country, model design, model validation, model alternative, and try out. But due to limitation of time and funding, the try-out stage is postponed for the next research.

\section{Need Assessment}

\section{Result}

RA-DWP has yet to succeed in escaping the mainstream; where generally people accept that education emphasizes more on knowledge and memorization, even for early age education. One of the reasons is that if it doesn't comply with the want and interest of the society, then RA-DWP will lose their interest, and the number of students will decline. But actually, this assumption isn't always right, a lot of parents really want to send their children to institutions with strong character, which will make their children become nice and devout (shaleh) in religion.The learning process in the RA curriculum of RA-DWP, prepared by the ministry of religious affairs, is packed with materials and memorization that are too demanding for toddlers. Meanwhile, the control and supervision by the supervisors are always based on the existing curriculum; therefore, the school finds it difficult to escape from the situation. This condition forces the teachers to opt for teaching and facilitating the students to learn. The way out of this situation can be taken if RA-DWP formulates its own curriculum by involving experts of child education and the students' parents. The curriculum can be consulted with the supervisor and later be reported to the ministry of religious affairs for a recommendation to be implemented. RA-DWP needs to have a clear concept in developing character education.

Since teachers' ability is more dominant in conveying materials, then the way the materials are presented becomes the activity to rely on. The ability to facilitate students to learn successfully through various means is still generally weak. Consequently, almost all of the learning activities throughout the day is conducted indoors. This is because most of the teachers at RA are not graduates of early age teacher training programs, they come from content teachers at schools. The lack of teacher training institutions which prepare teachers to teach at an RA is another reason. The limited supply of teachers with early age education background hasn't been addressed properly by the government. Hence, the solution for this situation is by improving teachers' competence to manage game-based early age education through trainings.

\section{Best Practice from Takasaka Kindergarten}

Early age education in Japan consists of two forms: hoikuen (day nursery) and youchien (kindergarten). Children enrolled at hoikuen are between 0-3 years old while children sent to youchien are between 4-5 years old. Youchien is under the coordination of ministry of education, whereas hoikuen is managed under the ministry of health and welfare. In 2006, the government introduced the ECEC (Early Childhood Care and Education) or in Japanese language called nintei kodomoen, which is adopted from UNESCO. This institution provides day care, kindergarten, children center, and community centers or play-parks.Takasaka Kindergarten, located in Nagoya city, is one of the local private-run education institutions. As a private-run institution, Takasaka Kindergarten has facility and management system that is not different from other state-run schools in the city, but the implementation is seen as more well-ordered and the environment is also cleaner.

As seen from the program and the educational operation, Takasaka Kindergarten emphasizes more on the development of the students' attitude and behaviors rather than on cognitive knowledge. Therefore, activities that involve affective and motoric development are dominant. Children are educated to become independent, responsible, sensitive and caring to the environment, appreciative to others, disciplined, and cooperative. The process is applied through various activities such as sports, arts and crafts instead of through explanation and memorization. Children are trained to perform good activities, and not to be lectured about goodness.

The principles of education at Takasaka Kindergarten that are relevant to be used as reference in designing the character education include:

2.1 Students must be trained to cooperate. They must understand their own roles and learn to appreciate others' roles. Through playing together, they learn to understand each other, and to apologize to one another when there is a disagreement. Activities like having meals together, playing in nature, performing rhythmic exercise indoors, doing sport outdoors, and singing together are included in the daily routine;

2.2 Students are guided to know the surrounding through various games which involve elements of earth, water, sand, trees, insects, and animals. They are also introduced to Japanese traditional games, such as takeuma (stilts), jump rope, and tree climbing. Students get used to playing in nature, they are asked to express the results of the play and interaction through painting; 
2.3 Students are trained in social sensitivity through music. That is why every teacher in Japan must be able to play the piano. Students switch from one activity to another not by verbal cue, but rather by a certain tune of music. Students can identify various rhythms and can adjust themselves with the activity expected by the teacher without being told to, or even being threatened to;

2.4 Students are trained to trust one another, that is why older students, as they normally do at home, must assist and help younger classmates who are having troubles doing a certain chore. They must not disturb and intimidate one another. In such a way, mutual trust can be developed, the way it is expected by the society;

2.5 The teacher acts as 'more knowledgeable other' who lives and stays with the students while they are at school. The teacher does not intervene, rather, he/she guides the students to learn, encourages them and helps them when they deal with problems;

2.6 The success of education is not seen from students' (academic) ability to read and write, rather, from students' ability to perform something. For an example, students are able to memorize their classmates' names; able to put away their learning tools by themselves; able to tell the teacher if any of their classmates is absent, and so on;

2.7 School must keep in touch with parents by informing them about the activities performed at school from day to day, the progress of the students' learning at school, and the kind of food served to the students.

\section{Character Education Model Design}

After performing need assessment at RA-DWP and digging for best practices at Takasaka Kindergarten, there needs to be a design for a character education, as shown below:

\subsection{Philosophy:}

Firstly, character cannot be taught, it must be lived and experienced. Cognitive learning which demands students to memorize must be replaced with practice and kinesthetic approach. This is due to the fact that students are not yet capable of abstract thinking and the fact that they are still fond of physical activities.

Secondly, educating through example, not through instruction. Students love to imitate what they see, therefore, teachers need to facilitate opportunities for students to see and imitate desirable actions, from the environment, and especially from the teacher. Thirdly, education must emphasize process, not result. In the process, students learn and try, and the habit of learning and trying is itself valuable for their own future lives.

Character education needs to involve all element of educational environment, from family, school, and the society. It is important for the school to develop intense cooperation with parents.

\subsection{Concept}

The concept offered to redesign learning at RA-DWP is called the ABK (Attitude Before Knowledge) model. This concept adopts Lickona's theory which states that character education includes: knowing the good, feeling the good, and doing the good, but the process of realization is adjusted to the children's limited ability to understand abstract concepts, and their tendency to imitate anything that they see; which requires exemplary conduct from the surrounding.

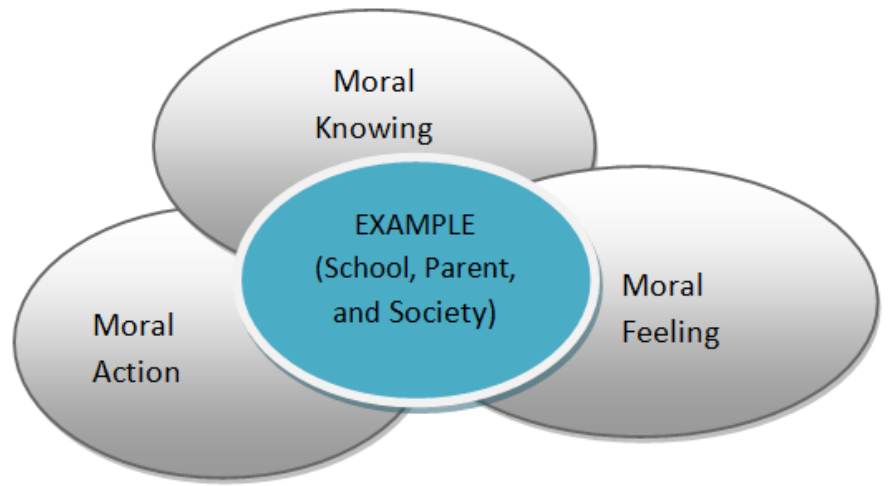

Picture 1: ABK Character Education Concept

\subsection{Approach}

Approach is one of the means used to solve a problem. In the context of this research, the problem being discussed is not partial, but holistic, from the learning process at school until cooperation between the school and the family and the society. Therefore, the approaches used in this model are also comprehensive, namely: the school's culture-based character education approach and the macro approach which involves cooperation between school, parents and the society. In terms of the relation between culture and behavior, Fullan in 'The Moral Imperative of School Leadership' explains that good changes in the social context will bring forward an encounter with new elements that will influence someone to be better. One fundamental point 
to be understood is that context can change behaviors. In this case, changing the context means changing the situation, changing the situation means changing the habit, continually changing the habit means changing the behaviors. Therefore, changing the context will change the behaviors. The way to change the behaviors can be done by changing or forming the community around them, by offering new beliefs and new habits. (Fullan, 2003: 29).

\subsection{Implementation:}

Teachers must give the example of desirable speech and behaviors in their interaction at school. Through varying activities and educative games teachers instill values and train good conducts. Moreover, teachers need to guide the students to always be disciplined at school for all matter from simple things such as putting away learning articles at their proper place, until the habit of standing in line to get their food and to enter the classroom. Teachers' habit of teaching students verbally must be significantly minimized. To operate such an applicative education model, cooperation between school, parents, and society must be well established. Parents must understand that teaching children at an early age with cognitive knowledge is a waste of time, and without any meaningful result, therefore, they will not demand that teachers will push forward to make their children look smart with various knowledge and memorization.
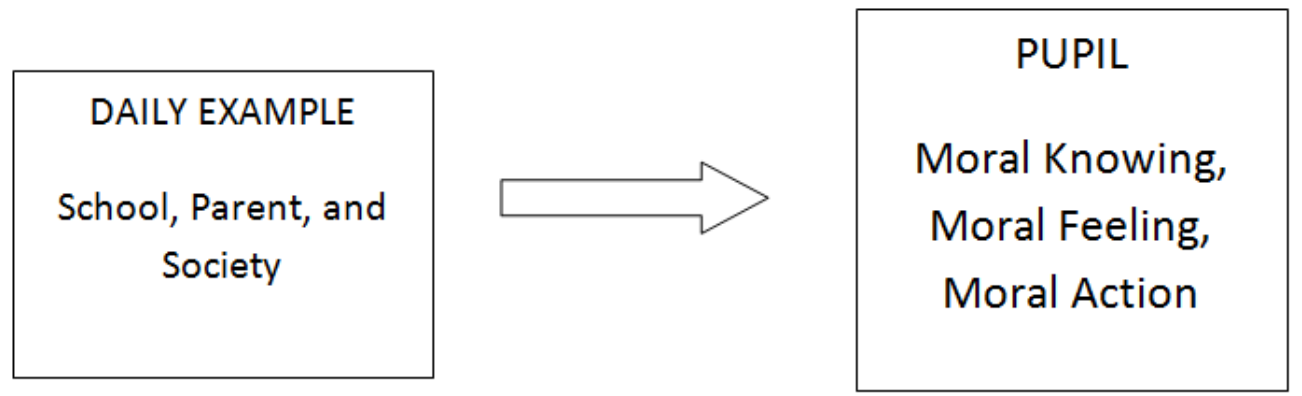

Picture 2; Implementation of ABK Concept

After the concept was discussed with experts at Universitas Islam Negeri, at Nagoya University, and at RA-DWP, it was then enriched by adding output elements which act as the feedback for the school in giving examples to the students. With such feedback, teachers will be able to revise and improve the concept so that the examples they give can be imitated by the students. The ABK model can be seen in the picture below:

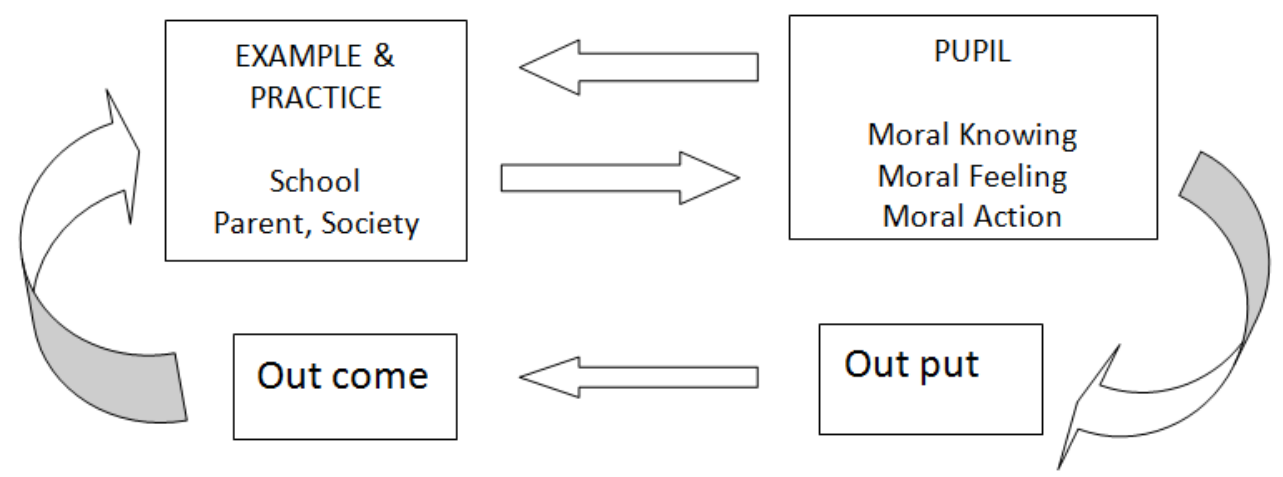

Picture 3; ABK model in Character Education for early-aged children at RA-DWP UIN Sunan Kaljjaga Yogyakarta

\section{Discussion}

Education, especially for preschool children, is not merely an effort to gain knowledge, but more importantly is an opportunity to develop character and to instill positive values in children (Clarizio, 1977, p. 4). Raudlatul Athfal UIN Sunan Kalijaga is one of the existing Islam-based preschool education institutions in Yogyakarta. Up to the present day, this institution is still prone to pressure by the bureaucracy and the society to provide a program which teaches children with academic materials as early as possible; the program must also include materials which deal with religion, such as reading and reciting Al-Qur'an and daily prayers. The slogan that is deeply ingrained in the collective mind of the society is that children must become 'pious scientists'. There is nothing wrong about such a slogan, but since in the implementation-stage the practice of education emphasizes knowledge and memorization, and not sufficiently balanced with students' character development, 
the result is far from what has been expected. The problem is, the education practice applied at RA-DWP is used as reference by prospective teachers who are doing the practicum teaching there, especially students from the Faculty of Tarbiyah Sciences and Faculty Teacher Training, UIN Sunan Kalijaga.

The model of early age education is crucial, because it serves as the foundation for the next levels of education. Unfortunately, there is a lack of understanding among Indonesian people that a child's character is more important than his/her knowledge. People enjoy more pride from smart kids than from kids with character. A child will be considered exceptional because he/she knows or can memorize a variety of knowledge information, not because he/she is honest or responsible. Even throughout the later stages of education - the elementary and secondary schools - people tend to choose schools with highest percentage of students graduated, not schools which provide various life skills for the students, both hard skills and soft skills. Education as a process of enculturation and acculturation for students (Young Pai, 1999, p. 231) is not well understood by the society.

This is a common phenomenon in the practice of education from preschool up to the later stages, it is well supported by government's policy, and people tend to view education merely as an academic process. It gets harder to correct the situation because the average ability of teachers at the early-age education centers is dominated by the tendency to teach knowledge rather than the ability to facilitate students to become more independent, social and responsible (Observation; November 2016). Due to these interrelated conditions, education in Indonesia focuses more on results rather than process. This process-oriented system forces students to rely on shortcuts rather than proper procedures. Aside from being unable to appreciate the processes of work, students are also willing to break the rules in order to achieve the result they desire. The facts that some students are willing to cheat during exams, and that some teachers have the habit of manipulating students' evaluation just so that students can get the preferred marks, are proves of education practices that are anti-value and are detrimental to character development. Later, when these students live in the society, they would easily violate the values of the society in order to gain their desired results. It's only natural that currently in Indonesia, desirable values such as mutual assistance, honesty, courtesy, and responsibility get weaker and weaker in their implementation. This is a prove that the aim to make the children become 'pious scientists' is impossible when we rely on an education system which ignores process.

In the context of education process, the learning strategy for preschool children needs to be adjusted to their age, that is, the age of playing. Playing activity is a child's basic need which has a considerable influence on his/her personality development (Hurlock, 1999). Playing is an initial means in the behavioral development because through playing, children acquire various intelligences at the same time, intellectual, emotional, social, and spiritual (Ismail, 2005). It is not easy to change the course of education, especially the one based on religion, because it closely touches the religious beliefs of the society. Even though the efforts taken is by directing the educational institution to become a place where desirable values are developed, people may wrongly perceive it as an effort of religious deprivation. When materials that involve religious knowledge and memorization are reduced, resistance from the society will be stronger. Thus, there needs to be proof that the education process which develops character does not deprive religion; rather it supports and strengthens the implementation of religious values.

The practice of education in Japan is very suitable for example, because the character of Japanese children is in line with the religious teachings. Although formally they do not study about religion, but because they practice the universal values of religion, the society's behavior is closer with religious teachings. How they practice education so that the result can be in line with the teachings of religion needs to be studied by teachers and education administrators. With acceptable proofs, it is expected that there will be a realization inside the teachers' minds to change their verbalistic education practice into a more aplicative one.

The concepts by Marzano (1985) and Bruner (1960) which embrace behaviors into elementary school teachings need to be considered by stakeholders. Marzano and Bruner saw that elementary education is aimed at developing behaviors and improving skills, therefore, preschool education needs to emphasize more on behavior development. Actually, the concept of Curriculum 2013, prepared by the government through Ministry of Education, has already included such elements, but the implementation is still far from expectation because it is against the people's general understanding. The curriculum, which emphasizes on affection, stumbled in its implementation because the perception inside the minds of people and some of the teachers hasn't changed. Marzano's and Bruner's concepts are formulated by the ministry of education as follows: 


\section{Keseimbangan antara Sikap, Keterampilan dan Pengetahuan Sesuai Jenjang Pendidikan}

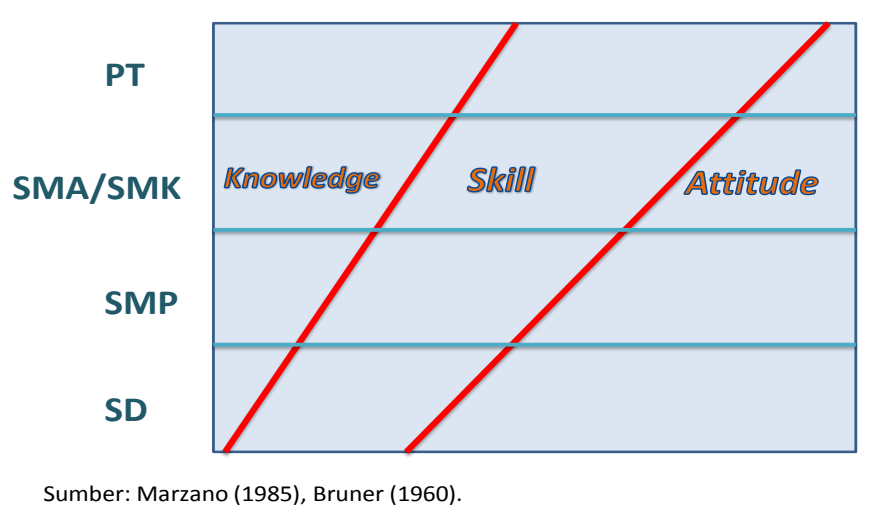

Picture 5: If Bruner's concept is added for early age education, and the skills factor is combined with attitude, then the picture will look like this:

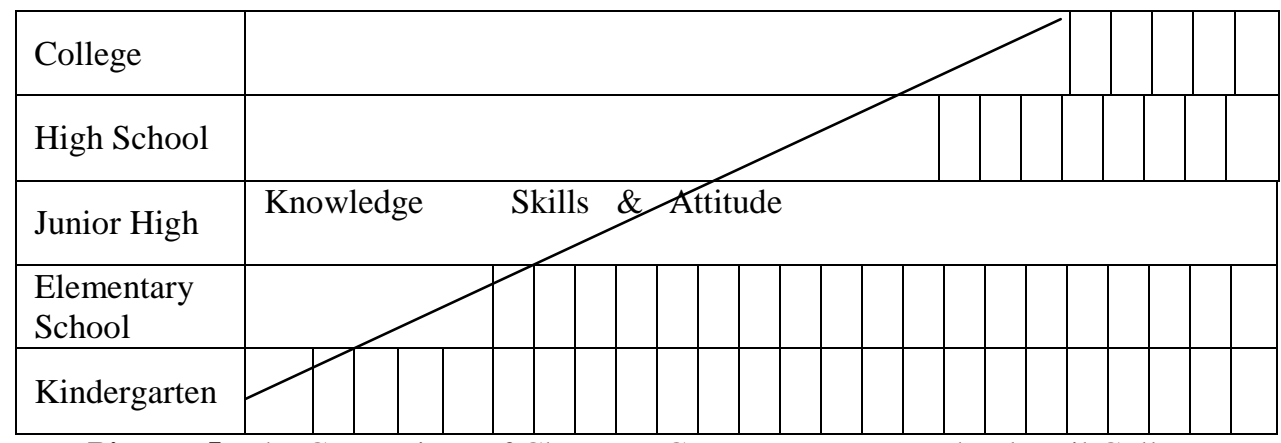

Picture 5: The Comparison of Character Contents From Preschool until College

To make such a change, researchers suggest a learning model for preschool by using the ABK (Attitude Before Knowledge) approach. This model will fundamentally change the education practice, which is cognitiveknowledge-oriented, into an education which is oriented to attitudes and behaviors. Although the ABK model offered here is meant to be used for preschool, researchers believe that it still needs to be practiced in the next stages of education until secondary school. If this can be achieved, then the phenomenon of students' tendency for irresponsible and anti-social behaviors will be dealt with. This means that some of the problems faced by Indonesia will gradually be solved.

The approach used to develop students' behaviors as observed from the best practices of Takasaka Kindergarten, Japan can be clustered into three: First, approach through direct examples from the teacher. This is put as the first priority because the teacher, as someone the students look up to, will be the one they imitate, he becomes the model to be copied by the students.Second, approach through school culture, which includes all activity performed at school, especially teacher-students interaction, companionship for students either individually or collectively, accustomization, and various educative games. Third, approach through cooperation with parents, society and government. The synergy between the three components with the school is the key to success of character education. This cooperation needs to be institutionalized in the form of a formal organization in order to be effectively implemented. Teacher needs to know what the children have been accustomed to at home by the parents, so that what has been developed as a good habit at school will be maintained and improved when students are at home. Moreover, in order that students feel comfortable and safe when at home and at school, a good relation must be maintained with the society because both family and school are located within a society. The available organization so far is between school and parents and society, minus the government. Consequently, many of the society's aspirations failed to reach the government, and vice versa, many of the governments' policies failed to be understood by the society. The ABK model of character education initially adopted Lickona's theory which stated that character education consists of moral knowing, moral feeling and moral action, but the application process is adjusted to the students' limited ability to understand abstract concepts but their tendency to imitate what they see and hear. Comprehensively, the model can be described as follows: 


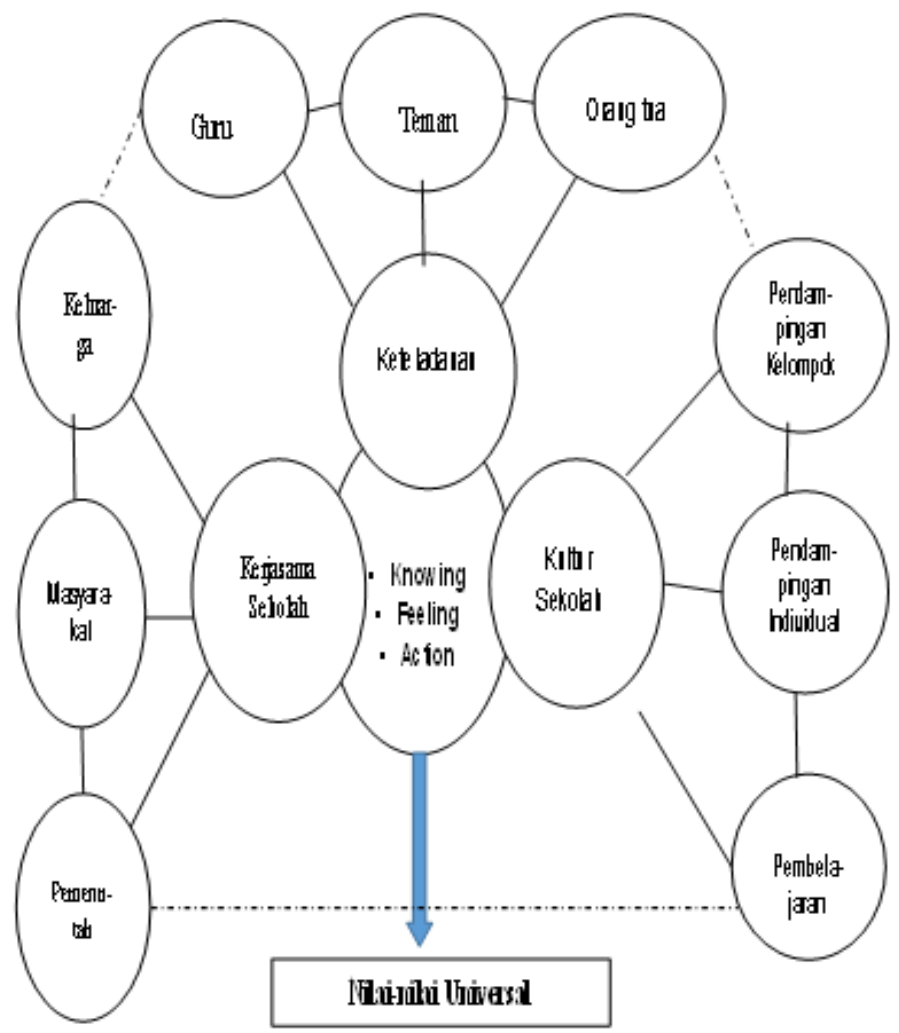

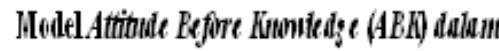 \\ Pestidiban Karalter}

Picture 6: Attitude Before Knowledge (ABK) Model in Character Education

Note:

It is important to pay attention that in implementing the model, teachers must abandon their old habit to emphasize content in the 'knowing' zone, which is cognitive in nature and which relies on verbalistic teaching process, teachers need to convert into giving precedence to 'action' and 'feeling' by providing more activities and practices which are applicative in nature.

Yogyakarta, 20 December 2016.

\section{Daftar Pustaka}

[1]. Andang Ismail. 2006. Education Games:Menjadi Cerdas dan Ceria Dengan Permainan Edukatif, Pilar Media, Yogyakarta.

[2]. Brady, Laurie. 1992. Curriculum Development, Fourth Edition, Prentice Hall, New York, London, etc.

[3]. Boyatziz, Richard E, Et All. 1995. Innovation in Professional Education Steps on A Journey From Teaching to Learning, JosseyBass Publisher, San Francisco.

[4]. Departemen Pendidikan dan Kebudayaan. 1999. Pendidikan Indonesia Mengatasi Krisis Menuju Pembaharuan. Jakarta.

[5]. Clarizio, Harey F, Et All. Contemporary Issues in Educational Psychology, Third Edition, Allyn and Brown, Inc. Boston etc.

[6]. Katz, Daniel \& Kahn, Robert L. 1965. The Social Psychology of Organizations, John Wiley \& Sons, Inc. New York.

[7]. Kolb, David A. 1984. Experiential Learning: Experience As The Source of Learning and Development, Prentice-Hall, Inc, etc, New Jersey.

[8]. Lickona, Thomas. 1991. Educating for Character: How Our Schools Can Teach Respect and Responsibility, Bantam Books, New York.

[9]. Lickona, Thomas. 2012. Mendidik untuk Membentuk Karakter: Bagaimna Sekolah dapat Mengajarkan Sikap Hormat dan Tanggung Jawab, Bumi Aksara, Jakarta.

[10]. Lickona, Thomas, 2012. Persoalan Karakter: Bagaimana Membantu Anak Mengembangkan Penilaian yang Baik, Integritas, dan Kebajikan Penting Lainnya, Bumi Aksara, Jakarta.

[11]. Sofiana, N Azizah (et.all), Laporan Kelompok Pelaksanaan Magang III Pendidikan Raudlatul Athfal RA DWP UIN Sunan Kalijaga, Yogyakarta, 2016

[12]. Young Pai. 1990. Cultural Foundations of Education, Merril Publishing Company, A Bell \& Howell Information Company, Ohio. 